\title{
Senil Katarakta Sahip Hastalarda Cerrahi Öncesi ve Cerrahi Sonrası Görme Keskinliğinin Depresyon ile İlişkisinin İncelenmesi: Çok Merkezli Çalışma
}

\author{
Investigation of the Relationship Between Visual Acuity and Depression Before and After Sur- \\ gery in Patients with Senile Cataract: A Multicenter Study
}

Abdullah BEYOGLU ${ }^{1}$, Mustafa BEYOGLU², Selma URFALIOGLU1 ${ }^{1}$, Dilek KUSASLAN AVCI ${ }^{3}$, Hüseyin Avni SAHIN ${ }^{3}$, Serek TEKIN ${ }^{4}$

\author{
${ }^{1}$ Sütçü Imam University, Faculty of Medicine, Department of Ophthalmolgy, Kahramanmaras, Turkey \\ ${ }^{2}$ Onikişubat District Health Directorate, Department of Family Medicine, Kahramanmaras, Turkey \\ ${ }^{3}$ Yuzuncu Y1l University, Faculty of Medicine, Department of Family Medicine, Van, Turkey \\ ${ }^{4}$ Yuzuncu Y1l University, Faculty of Medicine, Department of of Ophthalmolgy, Van, Turkey
}

\section{Özet}

Amaç: Senil kataraktı olan hastaların cerrahi operasyonu öncesi ve cerrahi sonrasında görme işlevine bağlı yașam kalitesinin depresyonla ilişkisini değerlendirmek.

Gereç ve Yöntemler: Bir Tıp Fakültesi Göz Hastalıkları Anabilim Dalı (1. Merkez) ve bir Devlet Hastanesi Göz Hastalıkları (2. Merkez) birimlerine başvuran senil katarakt tanısı ile cerrahi operasyon planlanan hastalara operasyon uygulanmadan önce ve operasyondan 1 ay sonra olmak üzere Geriatric Depression Scale (GDS) uygulandı. Hastaların tüm demografik verileri ile sistemik hastalıkları, operasyon öncesinde ve sonrasında en iyi düzeltilmiş görme keskinliği (EIDGK) kaydedildi. Verilerin değerlendirilmesinde SPSS 22.0 istatistik programı kullanıldı. P<0.05 anlamlı kabul edildi.

Bulgular: Hastaların 53'ü kadın (\%53) ve 47'si erkekti (\%47). Yaş ortalaması 68.32 99.20 (50-91 yaş) idi. Operasyon öncesi EIDGK Snellen eșeline göre $0.1 \pm 0.11$ sira $(0.05-0.3)$, operasyon sonras $10.80 \pm 0.16$ sira $(0.05-1.0)$ idi $(\mathrm{p}<0.05)$. Operasyon öncesi GDS puan ortalamas1 $11.69 \pm 3.80$ iken operasyon sonrasında 7.56 \pm 3.50 ' e düștügü tespit edildi ( $\mathrm{p}<0.01$ ). Cinsiyet, yaș ve kronik hastalık karşılaștırmasında operasyon öncesi ile operasyon sonrası GDS puan ortalamaları arasında anlamlı fark olmadığı görüldü. (Sırası ile, $\mathrm{p}=0.12 /=0.32 /=0.93$ ) Ancak eğitim düzeyi sınıflamasında gruplar arasında anlamlı fark olduğu saptand1. $(\mathrm{p}<0.01)$

Sonuç: Postoperatif senil katarakt hastalarının görme düzeylerindeki artıșa bağlı olarak yaşam kalitesi artmıs ve depresyona eğilim anlamlı bir șekilde azalmıştır. Bu azalma eğitim düzeyi arttıkça daha fazla gerçekleşmektedir.

Anahtar Kelimeler: Senil katarakt, Görme işlevi, Depresyon, Geriatrik depresyon skalası

\section{Abstract}

Objective: To evaluate the relationship between quality of life associated with visual acuity and depression in patients with senile cataracts before and after surgery.

Material and Methods: The Geriatric Depression Scale (GDS) was administered preoperatively and one month after surgery to patients scheduled for surgery with a diagnosis of senile cataract in a University Faculty of Medicine, Department of Ophthalmology and a State Hospital ophthalmology clinic. All demographic and systemic diseases data of patients, and best corrected visual acuity (BCVA) results before and after the operation were recorded. SPSS 22.0 statistics program was used to evaluate the data. $\mathrm{P}$ value of less than 0.05 was considered significant.

Results: Fifty-three of the patients were female (53\%) and 47 of them were male (47\%). The mean age was $68.32 \pm 9.20$ (50-91 years old). According to the Snellen scala, preoperative BCVA was $0.1 \pm 0.11(0.05-0.3)$ and postoperative was $0.80 \pm 0.16(0.05-1.0)(p<0.05)$. While the preoperative mean GDS score was $11.69 \pm 3.80$, it decreased to $7.56 \pm 3.50$ postoperatively $(\mathrm{p}<0.01)$. There was no significant difference between the pre-operative and postoperative GDS scores in the comparison of gender, age and chronic disease. (Respectively, $\mathrm{p}=0.12 /=0.32 /=0.93$ ). However, a significant difference was found between the groups in the classification of education level $(\mathrm{p}<0.01)$

Conclusion: The quality of life of patients with postoperative senile cataracts has increased due to the increase in vision levels and the tendency to depression has decreased significantly. This decrease occurs more and more the higher the education level.

Key words: Senile cataract, Visual function, Depression, Geriatric depression scale

Yazışma Adresi: Abdullah BEYOĞLU,Sütçü İmam Üniversitesi Tıp Fakültesi Hastanesi Göz Hastalıkları ABD, Kahramanmaraş, Türkiye Telefon: +9005309604594, Mail: drabeyoglu@gmail.com

ORCID No (Sırasıyla): 000-0003-1948-7755, 0000-0003-0367-5794, 0000-0002-3709-6988, 0000-0002-5412-1030, 0000-0002-8651-3469,

0000-0002-6660-8313

Geliş tarihi: 21.09.2020

Kabul tarihi: 12.10.2020

DOI: $10.17517 / \mathrm{ksutfd} .795291$ 


\section{INTRODUCTION}

Senile cataract is one of the leading causes of vision loss in the world (1).With the increasing life expectancy and increasing elderly population, the problem of senile cataract continues increasingly $(1,2)$. It has been reported that at the end of this year, $17.7 \%$ of the population in the USA will consist of geriatric individuals, and this rate will reach $22 \%$ in the Netherlands (3).According to literature data, it is stated that there are 5.7 million elderly individuals (7.5\%) in our country, and this number will be 8.6 million (10.2\%) in 2023 $(3,4)$. This situation appears as a global public health and serious economic problem (1). Good vision is an important consideration for physical and cognitive function $(1,2,5)$. Disruptions in vital activities may occur with the decrease in visual function in patients with cataract. The problems vary from person to person, but are related to the type and degree of cataracts (6). Disturbances in vital functions can lead to mental pathologies such as depression, especially in elderly individuals $(1,2,5,7)$. The rate of not being able to maintain self-care, performing daily life activities, being dependent on others and living with different obstacles increases in the elderly $(7,8)$. One of the causes of disability is vision loss. Since vision loss directly affects the independence of the individual, it can lead to feeling dependent on others, useless, decreased self-esteem, and depression (8). Cataract surgery is a highly effective treatment that can result in almost instant vision improvement (5). There are data showing that cataract surgery can contribute positively to the improvement of depressive symptoms in patients $(5,8)$. In this study, we aimed to investigate the relation of visual impairment with depression by applying GDS questionnaire to senile cataract patients before and one month after surgery.

\section{MATERIAL and METHODS}

Our study was carried out prospectively in central 1, Department of Ophthalmology and central 2, Eye Diseases Unit. Our study was conducted in accordance with the declaration of Helsinki by obtaining permission from the local ethics committee (decision number 03 date: 07/03/2017). Our study included 100 volunteers over 50 years of age, who were admitted to both centers with low vision complaints between March 2017 and September 2017, and who were found to have senile cataract after ophthalmologic examination and were recommended surgery. Patients who had difficulties in communicating, who could not attend the control examination, who had previously undergone ocular surgery, who had cataracts under the age of 50, and had cataracts for reasons other than senile cataracts were not included in the study. GDS was chosen because it measures the psychological symptoms of depression, not somatic symptoms that might be confused with cataract-related symptoms. The data were collected by face to face interview method. This method was developed by Yesevage et al in 1983. The validity and reliability study of this scale for the Turkish population was conducted by Associate Professor Turan Ertan of Cerrahpaşa Faculty of Medicine, Istanbul University.(test-retest con- sistency, $\mathrm{r}=0.77$; internal consistency $\mathrm{a}=0.92$ ). GDS consists of 30 questions based on self-report. It is prepared in such a way that elderly people can easily answer "yes" or "no". The scoring of the scale was as follows: 0-10 points "no depression", 11-13 points "possible depression", 14 and above points "definite depression". When the threshold value for GDS is 14 points, its specificity approaches $100 \%$. The scores obtained by the same researchers $(\mathrm{AB}, \mathrm{MB}, \mathrm{ST})$ were evaluated. Those who scored between 11 and 14 in the scale were considered as probable depression, and those who scored 14 and above closer to depression.

\section{Staticical Analysis}

SPSS 22.0 was used for statistical analysis. The compatibility of the data to normal distribution was evaluated using the Shapiro-Wilk test. Categorical data were analyzed using the chi-square test. In group comparisons, it was observed that the data conformed to normal distribution. For this reason, Paired-samples $\mathrm{T}$ test was used in the analysis of dependent data and Independent-samples $\mathrm{T}$ test was used in the analysis of independent groups. Continuous data were expressed as mean \pm standard deviation (SD) values and categorical data as number ( $\mathrm{n}$ ) and percentage (\%). P value less than 0.05 was considered statistically significant.

\section{RESULTS}

A total of 100 patients were included in our study, with 50 patients from two centers. $53(53 \%)$ of the patients included in the study were female and $47(47 \%)$ were male. The mean age of the patients was $68.32 \pm 9.20$ (50-91 years old) (Women:67.96 \pm 9.85 years, Men:69.05 \pm 8.72 years). There was no statistically significant difference between the genders in terms of age $(p=0.82)$. The mean GDS score of the individuals before the operation was $11.69 \pm 3.8$ and the mean GDS score after the operation was $7.56 \pm 3.5$. A statistically significant difference was found in terms of GDS within the centers and in total $(\mathrm{p}<0.01)$ (Table 1$)$. Preoperative and postoperative mean visual acuities were $0.15 \pm 0.12$ and $0.8 \pm 0.16$, respectively. There was a statistically significant difference in visual acuity before and after surgery $(\mathrm{p}<0.01)$ (Table $\mathbf{1})$.

When the GDS results were compared in terms of age, gender and chronic diseases, there was no significant difference before and after the operation in terms of GDS change between patients aged 50-65 and older than 65 years $(p=0.32)$. When the GDS results between genders were examined, there was no statistical difference between preoperative and postoperative $(\mathrm{p}=0.123)$. In the presence of chronic disease, there was no statistical difference between the change in GDS before and after the surgery $(\mathrm{p}=0.93)$. No significant difference was found in the comparisons in terms of age, gender and chronic disease. As the education level increases, a positive change is observed in the GDS score. Highly educated patients apply to the hospital earlier for treatment. In our study, there was a significant difference before and after surgery in terms of the relationship between educational status and GDS change $(\mathrm{p}<0.01)$ (Table 2). 
Table 1. Change of visual acuity and GDS with surgery.

\begin{tabular}{|c|c|c|c|c|c|c|c|c|c|}
\hline & \multicolumn{5}{|c|}{ GDS } & \multicolumn{4}{|c|}{ Visual Acuity } \\
\hline & & Min. & Max. & Mean & $P$ value & Min. & Max. & Mean & $P$ value \\
\hline \multirow[t]{2}{*}{ 1.Center } & Preop & 5 & 26 & $14.58 \pm 4.75$ & \multirow[t]{2}{*}{$<0.01$} & 0.05 & 0.40 & $0.09 \pm 0.07$ & \multirow[t]{2}{*}{$<0.01$} \\
\hline & Postop & 1 & 21 & $10.00 \pm 4.39$ & & 0.05 & 1.00 & $0.76 \pm 0.17$ & \\
\hline \multirow[t]{2}{*}{ 2.Center } & Preop & 3 & 25 & $11.32 \pm 5.31$ & \multirow[t]{2}{*}{$<0.01$} & 0.05 & 0.50 & $0.21 \pm 0.12$ & \multirow[t]{2}{*}{$<0.01$} \\
\hline & Postop & 1 & 20 & $6.88 \pm 4.48$ & & 0.50 & 1.00 & $0.85 \pm 0.14$ & \\
\hline \multirow[t]{2}{*}{ Total } & Preop & 3 & 26 & $12.95 \pm 5.27$ & \multirow[t]{2}{*}{$<0.01$} & 0.05 & 0.5 & $0.15 \pm 0.12$ & \multirow[t]{2}{*}{$<0.01$} \\
\hline & Postop & 1 & 21 & $8.44 \pm 4.68$ & & 0.05 & 1.00 & $0.80 \pm 0.16$ & \\
\hline
\end{tabular}

${ }^{*}$ Paired-samples $\mathrm{T}$ test.

GDS: Geriatric Depression Scale

$\mathrm{p}$ value of $<0.05$ was considered as significant

Table 2. Relationship of age, gender, chronic illness, and education status with GDS and visual acuity.

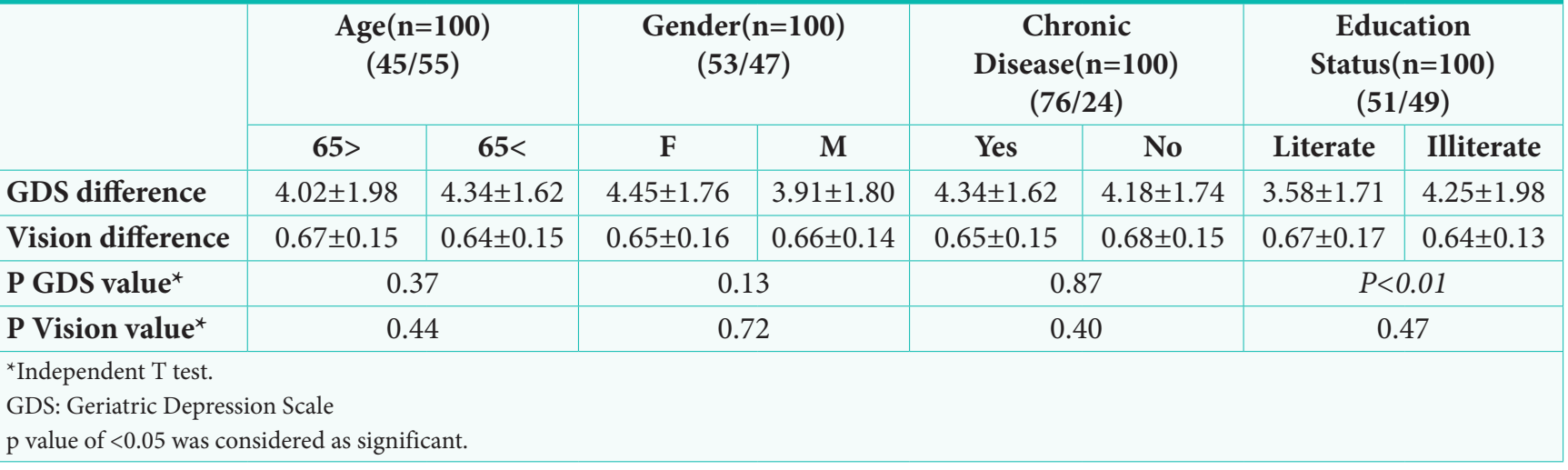

\section{DISCUSSION}

Having an adequate level of vision is an important consideration for physical and cognitive function. The decrease in vision can cause mental disorders, limitation in daily activities, various disabilities and mortality $(1,2)$. Vision loss occurs more with aging. One of the major causes of visual impairment in elderly people is senile cataract (7). Cataract affects all segments of the society due to the increase in life expectancy $(1,5,6)$. Cataract surgery is a treatment that can significantly restore vision after surgery $(2,5)$. After improvement in visual acuity, physical, cognitive functions and mental status improve in patients (2). There are several studies in the literature showing improvement in the depressive symptoms of patients after surgery $(1,2,5,10)$. Palagyi et al. (9) reported that patients with shorter waiting times for cataract surgery experienced earlier return to activities, increased confidence, and less anxiety. Harwood et al. (10) reported a significant reduction in symptoms of depression in those who had rapid cataract surgery within one month compared to a routine 12 -month waiting period in the UK. Pellegrini et al. (2) stated in their study that vision loss caused by senile cataracts has a strong relationship with depressive symptoms, and that it can cause depression and cognitive disorders in elderly people, worsening the outcome of many diseases, and may cause disability and mortality. Kheirkhah et al. (7) stated in their study that there is a significant relationship between increased visual acuity after surgery and a significant decrease in depressive symptoms. Similarly, we found a decrease in GDS scores after surgery in our study. With the increase in visual acuity, people realize their environmental communication more easily. We think that the increase in communication has a positive effect on rebuilding the hormonal and biological order of the elderly people by reducing their introversion. In addition to the decrease in visual perception, cataracts may also cause a decrease in non-visual light transmission due to the density it creates $(11,12)$. Miyata et al. (5) reported that there was an increase in the amount of light reaching the retina after cataract surgery. They say that this is very important for the regulation of the biological clock. They reported that people who could not synchronize the circadian rhythm due to insufficient amount of light had a tendency to depression and a decrease in cognitive level. Ayaki et al. (13) reported that cataract surgery increases the quality of sleep by increasing the light transmittance required to maintain the circadian rhythm. Therefore, they reported that the transparent intraocular lens implanted surgically instead of the increased opacity lens increased the amount of light hitting the retina, and the increased melatonin secretion contributed positively to the regulation of the circadian rhythm, increasing the cognitive level and reducing depression $(5,13,14)$. We did not examine the melatonin levels of the patients in our study. However, we think that the decrease in 
GDS scores and positive changes in life styles after cataract surgery indicate an improvement in the circadian rhythm. Wang et al. (1) reported that depressive symptoms occurring in cataract patients were not only due to decreased visual acuity, but also that halos caused by light reflections, contrast impairment, and decreased light adaptation caused depressive symptoms. In addition, they say that the thought and fear of having surgery increases the level of depression. They report that all these symptoms cause more severe depressive symptoms in patients with senile cataracts without formal education. They associated this situation with people with high education levels having a better ability to cope with life difficulties. They reported that the inability to perceive the potential gains that can be achieved with surgery and to have insufficient knowledge will increase depressive symptoms by causing delays in treatment administration. In our study, a statistically significant relationship was found between the educational status of patients with senile cataracts and GDS scores. Depressive symptoms decreased as the education level increased. We can attribute this to the fact that patients notice the changes in their vision level early due to the increase in their socio-cultural level and reach the surgical intervention in the ideal time by applying to the hospital earlier. Pellegrini et al. (2) stated that they did not have clear information about whether the depressive improvement effect would be permanent in the long term after cataract surgery. They predict that when there is a problem caused by cataracts or surgical procedures, the effect may gradually decrease with time after the operation. In another study, it was reported that cataract surgery had positive effects on preventing cognitive decline during the 13-year follow-up period (15). In a study using magnetic resonance (MR) in cataract patients, an increase in brain gray matter volume, frequency and signal improvements in areas related to vision and cognition were found after surgery (16). Long-term follow-up was not performed in our study. In our study, the GDS test scores applied to patients in two different centers one month after the operation was found to be significantly lower than the preoperative test scores. Patients whose vision level has decreased due to the opacification that may occur after a long period in the posterior capsule of lenses implanted into the eye should be evaluated separately. Such a study will be a guide to understand whether the improvement in depressive symptoms will continue. The limitations of our study are that the melatonin level affecting the cognitive level was not measured and the patients were not re-evaluated in the long term after surgery. We did not divide chronic diseases into subgroups. However, our study seems to be strong compared to other studies in the literature due to its multi-center nature, including patients with a socio-cultural difference and chronic diseases. As a result, due to the increase in vision levels of patients with postoperative senile cataract, the quality of life has increased and the tendency to depression has decreased significantly. It can be said that early intervention in patients with senile cataracts contributes to social life by improving the quality of life of patients and preventing the tendency to depression. In order to better understand the long-term effect of cataract surgery on depression, longer-term and large-scale studies that take hormone tests into account are needed.

\section{Authors' contributions}

$\mathrm{AB}$ and DKA designed it. $\mathrm{AB}, \mathrm{ST}$ and $\mathrm{MMB}$ collected data. $\mathrm{AB}$ and $\mathrm{SU}$ made statistics. $\mathrm{AB}, \mathrm{MMB}$ and $\mathrm{HAS}$ scanned the literature. $\mathrm{AB}$ and $\mathrm{MMB}$ wrote.

\section{Conflict of Interest and Financial Status}

Our study has not been financed by an institution and institution. In this study, there is no conflict of interest among the authors on any subject

\section{REFERENCES}

1. Wang H, Sun HP, Wang P, Xu Y, Pan CW. Cataract and Depressive Symptoms among Older Chinese Adults. Optom Vis Sci. 2016 Dec;93(12):1479-84.

2. Pellegrini M, Bernabei F, Schiavi C, Giannaccare G. Impact of Cataract Surgery on Depression and Cognitive Function: Systematic Review and Meta-analysis. Clin Exp Ophthalmol. 2020 Jul;48(5):593-601.

3. Gul HL, Evcili G, Karadaş O, Gul ES. Geriatric Depression and Associated Risk Factors: The Level of Depression Symptom at Elderly Living in Nursing Home. J Clin Anal Med. 2012;3(3):302-4.

4. Tel H, Tay BN, Canbay M, Akaya I, Yalçınkaya S. Disability and Depression among The Elderly People with Chronic Physical Disease. F. N. Hem. Derg 2014;22(2):69-75.

5. Miyata K, Toshikawa T, Morikawa M, Mine M, Okamoto N, Kurumatani N, et al. Effect of Cataract Surgery on Cognitive Function in Elderly: Results of Fujiwara-kyo Eye Study. PLoS One. 2018 Feb 20;13(2):e0192677.

6. Bayraktar S, Cebeci Z, Gozum N, Gucukoglu A. Assessment of Vision-Related Quality of Life Before and After Cataract Surgery Among Senile Cataract Patients. Clinical Research. J Ist Faculty Med. 2016;79(2):54-60.

7. Kheirkhah F, Roustaei GA, Abivardi EM, Hamidia A, Kutenai SJ. Improvement in Cognitive Status and Depressive Symptoms Three Months after Cataract Surgery. Caspian J Intern Med. Fall 2018;9(4):386-92.

8. Zhang D, Fan Z, Gao X, Huang W, Yang Q, Li Z, et al. Illness Uncertainty, Anxiety and Depression in Chinese Patients with Glaucoma or Cataract. Sci Rep. 2018 Aug 3;8(1):11671.

9. Palagyi A, Rogers K, Meuleners L, McCluskey P, White A, Ng JQ, et al. Depressive Symptoms in Order Adults Awaiting Cataract Surgery. Clin Exp Ophthalmol. 2016 Dec;44(9):789-96.

10. Harwood RH, Foss AJ, Osborn F, Gregson RM, Zaman A, Masud T. Falls and Health Status in Elderly Women Following First Eye Cataract Surgery: A Randomised Controlled Trial. Br J Ophthalmol. 2005;89:53-9.

11. Kessel L, Lundeman JH, Herbst K, Andersen TV, Larsen M. Age-related Changes in The Transmission Properties of The Human Lens and Their Relevance to Circadian Entrainment. J Cataract Refract Surg. 2010;36(2):308-312.

12. Turner PL, Mainster MA. Circadian Photoreception: Ageing and The Eye's Importent role in Systemic Health. Br J Ophthalmol. 2008;92(11):1439-44.

13. Ayaki M, Muramatsu M, Negishi K, Tsubota K. Improvements in Sleep Quality and Gait Speed After Cataract Surgery. Rejuvenation Res. 2013;16:35-42. 
14. Nishi T, Saeki K, Miyata K, Yoshikawa T, Ueda T, Kurumatani N, et al. Effects of Cataract Surgery on Melatonin Secretion in Adults 60 Years and Older: A Randomized Clinical Trial. JAMA Ophthalmol. 2020 Mar 5. Doi: 10.1001/jamaophthalmol.2020.0206. Online ahead of print.

15. Maharani A, Dawes P, Nazroo J, Tampubolon G, Pendleton N, SENSE-Cog WP 1 Group. Cataract Surgery and Age-releted Cognitive Decline: A 13-year Follow-up of The English Longitudinal Study of Ageing. PLoS One. 2018; 13:e0204833.

16. Lin H, Zhang L, Lin D, Chen W, Zhu Y, Chen C, et al. Visual restoration after cataract surgery promotes functional and structural brain recovery. EBioMedicine. 2018;30:52-61. 